\title{
Hexose-6-phosphate dehydrogenase confers oxo-reductase activity upon 11ß-hydroxysteroid dehydrogenase type 1
}

\author{
Iwona J Bujalska, Nicole Draper ${ }^{*}$ Zoi Michailidou ${ }^{1, *}$, Jeremy W Tomlinson, \\ Perrin C White², Karen E Chapman'1, Elizabeth A Walker and Paul M Stewart \\ Division of Medical Sciences, Endocrinology, Institute of Biomedical Research, Medical School, University of Birmingham, Birmingham, B15 2TT, UK \\ ${ }^{1}$ Endocrine Unit, Molecular Medicine Centre, University of Edinburgh, Western General Hospital, Crewe Road, Edinburgh, EH4 2XU, UK \\ ${ }^{2}$ Paediatrics, University of Texas Southwestern Medical Center, Harry Hines Boulevard, Dallas, TX, USA
}

(Requests for offprints should be addressed to P M Stewart; Email: p.m.stewart@bham.ac.uk)

*(N Draper and Z Michailidou contributed equally to this work)

\begin{abstract}

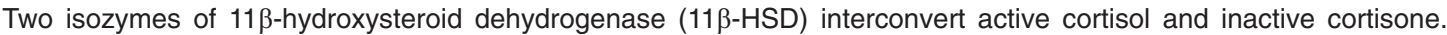
$11 \beta$-HSD2 (renal) acts only as a dehydrogenase, converting cortisol to cortisone. 11 $\beta$-HSD1 (liver) is a bi-directional enzyme in cell homogenates, whereas in intact cells it typically displays oxo-reductase activity, generating cortisol from cortisone. We recently established that cortisone reductase deficiency is a digenic disease requiring mutations in both the gene encoding $11 \beta-H S D 1$ and in the gene for a novel enzyme located within the lumen of the endoplasmic reticulum (ER), hexose-6-phosphate dehydrogenase $(\mathrm{H} 6 \mathrm{PDH})$. This latter enzyme generates NADPH, the co-factor required for oxo-reductase activity. Therefore, we hypothesized that H6PDH expression may be an important determinant of $11 \beta$-HSD1 oxo-reductase activity. Transient transfection of chinese hamster ovary $(\mathrm{CHO})$ cells with $11 \beta$-HSD1 resulted in the appearance of both oxo-reductase and dehydrogenase activities in intact cells. Co-transfection of 11 $\beta$-HSD1 with H6PDH increased oxo-reductase activity whilst virtually eliminating dehydrogenase activity. In contrast, H6PDH had no effect on reaction direction of $11 \beta$-HSD2, nor did the cytosolic enzyme, glucose-6-phosphate dehydrogenase (G6PD) affect 11 $\beta$-HSD1 oxo-reductase activity. Conversely in HEK 293 cells stably transfected with $11 \beta$-HSD1 cDNA, transfection of an H6PDH siRNA reduced 11 $\beta$-HSD1 oxo-reductase activity whilst simultaneously increasing $11 \beta-H S D 1$ dehydrogenase activity. In human omental preadipocytes obtained from 15 females of variable body mass index (BMI), H6PDH mRNA levels positively correlated with 11 $\beta$-HSD1 oxo-reductase activity, independent of 11 $\beta$-HSD1 mRNA levels. H6PDH expression increased 5-3-fold across adipocyte differentiation $(P<0.05)$ and was associated with a switch from $11 \beta-H S D 1$ dehydrogenase to oxo-reductase activity. In conclusion, $\mathrm{H} 6 \mathrm{PDH}$ is a crucial determinant of $11 \beta$-HSD1 oxo-reductase activity in intact cells. Through its interaction with $11 \beta$-HSD1, H6PDH may represent a novel target in the pathogenesis and treatment of obesity.
\end{abstract}

Journal of Molecular Endocrinology (2005) 34, 675-684

\section{Introduction}

The enzyme $11 \beta$-hydroxysteroid dehydrogenase type 1 (11 $\beta$-HSD1, EC $1 \cdot 1 \cdot 1 \cdot 146)$ inter-converts active cortisol and inactive cortisone, and therefore represents an important regulatory mechanism for tissue specific glucocorticoid receptor (GR) activation. 11 $\beta$-HSD 1 resides within the lumen of the endoplasmic reticulum (ER) (Ozols 1995, Odermatt et al. 1999) and is bi-directional, being able to catalyze both the dehydrogenase (cortisol to cortisone) and oxo-reductase (cortisone to cortisol) reactions (Agarwal et al. 1989). In vivo and in intact cells, oxo-reductase activity predominates (Bujalska et al. 1997a, Jamieson et al. 2000, Masuzaki et al. 2001), but in cellular homogenates or in purified preparations, the enzyme behaves as a dehydrogenase (Lakshmi \& Monder 1988); oxo-reductase activity can only be recovered in these situations upon the addition of an artificial NADPH re-generation system, such as can be provided by the activity of glucose-6-phosphate dehydrogenase (G6PD) (Agarwal et al. 1990, Walker et al. 2001).

$11 \beta$-HSD1-mediated oxo-reductase activity in liver and adipose tissue may modulate development of the metabolic syndrome. Exposure to cortisol increases hepatic glucose output (Jones et al. 1993) and adipocyte differentiation (Hauner et al. 1987). Selective inhibitors have shown beneficial results in improving insulin sensitivity and causing weight loss (Alberts et al. 2003, Livingstone \& Walker 2003), but the factors determining oxo-reductase activity per se have remained elusive.

Hexose-6-phosphate dehydrogenase (H6PDH, EC $1 \cdot 1 \cdot 1 \cdot 47$ ) performs the first two steps of a pentose phosphate pathway which is believed to exist within the ER lumen (Bublitz \& Steavenson 1988). It is responsible for converting glucose-6-phosphate to 
6-phospho-gluconolactone, thereby generating NADPH (Kimura et al. 1979, Stegeman \& Klotz 1979). Based on genetic evidence, we have argued that reduced H6PDH activity, together with reduced expression of $11 \beta$-HSD 1 , underlies cortisone reductase deficiency (CRD). Women affected with GRD have polycystic ovary syndrome (PCOS) with menstrual irregularity, hirsutism and infertility. They are unable to generate cortisol from cortisone due to defective 11ß-HSD1 oxo-reductase activity (Nikkila et al. 1993, Jamieson et al. 1999) resulting in activation of the hypothalamic-pituitary-adrenal axis and adrenocorticotrophin (ACTH) driven adrenal androgen excess (Biason-Lauber et al. 2000, Laing et al. 2002). These patients carry coding-sequence mutations in the gene encoding $\mathrm{H} 6 \mathrm{PDH}(\mathrm{H} 6 \mathrm{PD})$ in association with intronic mutations in the $11 \beta$-HSD1 gene $(H S D 11 B)$ that reduce gene transcription (Draper et al. 2003).

Here we show that H6PDH has the potential to profoundly influence $11 \beta$-HSD 1 by affecting the reaction direction in intact cells and also demonstrate that in primary cultures of human omental preadipocytes, levels of $\mathrm{H} 6 \mathrm{PDH}$ expression predict oxo-reductase activity.

\section{Materials and methods}

\section{Patients}

Omental adipose tissue biopsies were obtained from 15 female patients undergoing elective abdominal surgery (median age 40 years, range 28-60 years, median body mass index (BMI) $29 \cdot 3 \mathrm{~kg} / \mathrm{m}^{2}$, range $19 \cdot 7-39 \cdot 2$ ). All gave their full informed, written consent. The study had the approval of the local research ethics committee.

\section{Primary culture}

Omental preadipocytes were isolated as previously reported (Bujalska et al. 1997b), seeded in a 24-well tissue culture dish and cultured to confluence (up to 6 days) in DMEM/F12 media supplemented with $10 \%$ fetal calf serum. At this point, $11 \beta$-HSD1 oxo-reductase assays were performed, protein concentration measured and total RNA extracted. In a further set of experiments, omental preadipocytes were isolated from adipose tissue obtained at elective surgery $(n=12)$. Preadipocytes were differentiated into mature adipocytes according to an established protocol (Hauner et al. 1987). Briefly, after cell washing (day 1), 11 $\beta$-HSD1 oxo-reductase and dehydrogenase activities were measured and total RNA extracted. Cells were then differentiated for a further 14 days, $11 \beta-H S D 1$ activity measured, total RNA extracted and H6PDH and 11ß-HSD1 expression measured by real-time PCR as described below.

\section{Transient transfection of chinese hamster ovary (CHO) cells}

Full length cDNA encoding rat $11 \beta-H S D 1$ was subcloned into pDR2 (Clontech). The pDR2 derivative encoding human 11 -HSD2 cDNA has been previously described (Brown et al. 1996). The coding region of human H6PDH cDNA (Mason et al. 1999) was subcloned into pcDNA3·1 (Invitrogen). PBADHuG6PD, encoding human G6PD (Persico et al. 1986), was kindly provided by Dr P Mason (Imperial College, London, UK). Chinese hamster ovary (CHO) cells were maintained in Dulbecco's modified Eagle's medium supplemented with $10 \%$ fetal bovine serum, $100 \mathrm{U} / \mathrm{mL}$ penicillin, $100 \mu \mathrm{g} / \mathrm{mL}$ streptomycin. Twenty-four hours prior to transfection, $\mathrm{CHO}$ cells were seeded at $2 \times 10^{5}$ cells $/ 60 \mathrm{~mm}$ dish and transfected with a total of $21 \mu \mathrm{g}$ DNA using the calcium phosphate procedure (Voice et al. 1996). DNA consisted of $10 \mu \mathrm{g}$ pDR2 vector or $11 \beta$-HSD expression plasmid, $10 \mu \mathrm{g}$ pcDNA3 1 , H6PDH or pBADHuG6PD plasmid and $1 \mu \mathrm{g}$ pCH110 (Amersham) encoding $\beta$-galactosidase; the last plasmid was an internal control for transfection efficiency. In each experiment, transfections were independently carried out in sextuplet; three for each assay of $11 \beta$-HSD activity in oxo-reductase or dehydrogenase direction after adding ${ }^{3} \mathrm{H}$-steroid to the medium $2 \mathrm{~h}$ after transfection. Forty two hours after transfection, cells were lysed and $\beta$-galactosidase activity assayed, as previously described (Williams et al. 2000), to verify that transfection efficiency was similar between transfections.

\section{siRNA experiments}

HEK 293T1 cells were used for siRNA transfection. They were derived from human embryonic kidney cells (HEK 293) by stable transfection with human $11 \beta$ HSD1 cDNA in the vector pCR3 (Invitrogen, UK) and display both dehydrogenase and oxo-reductase activities (Bujalska et al. 1997a). Cells were plated at 3.0 $010^{4}$ cells per well in a 24-well tissue culture plate. Following $24 \mathrm{~h}$ in culture, cells were transfected with $100 \mathrm{nM}$ H6PDH siRNA (Ambion siRNA ID 14371), $11 \beta$-HSD 1 siRNA (Ambion siRNA ID 16305), or SilencerTM Negative Control \#1 siRNA (Ambion, Huntingdon, Cambs, UK) using $3 \mu \mathrm{l}$ per well siPORT Amine Transfection Agent (Ambion) according to the manufacturer's protocol. Forty eight hours after transfection, $11 \beta$-HSD1 assays were performed as described below and the cells were subsequently harvested for protein and total RNA. H6PDH and $11 \beta$-HSD 1 mRNA levels were measured by real-time RT-PCR with $18 \mathrm{~S}$ rRNA as the internal standard. Target gene expression was calculated as fold change compared with the negative control siRNA gene expression. All experiments were carried out in triplicate. 


\section{RNA extraction and reverse transcription}

Total RNA was extracted using a single step extraction method (Tri Reagent, Sigma). One microgram of total RNA was reverse transcribed using random hexamers in $20 \mu \mathrm{l}$ volume according to manufacturer's protocol (Promega).

\section{Real-time PCR}

$11 \beta$-HSD 1 and H6PDH mRNA levels were measured by real-time PGR using an ABI 7700 system (Perkin-Elmer, Biosystems, Warrington, UK). PCR was performed in $25 \mu \mathrm{l}$ reactions on 96-well plates. Reactions contained TaqMan universal PGR master mix (Applied Biosystems, Warrington, Cheshire, UK), $900 \mathrm{nmol}$ primers, 100-200 nmol TaqMan probe and 25-50 ng cDNA. All reactions were multiplexed with primers specific for 18S rRNA (provided as a pre-optimized mix; Perkin-Elmer, Beaconsfield, Bucks, UK) as an internal reference. All target gene probes were labeled with the fluorescent label FAM, and the $18 \mathrm{~S}$ probe with the fluorescent label VIC. Reactions were as follows: $50{ }^{\circ} \mathrm{C}$ for $2 \mathrm{~min}, 95^{\circ} \mathrm{C}$ for $10 \mathrm{~min}$, and then 44 cycles of $95^{\circ} \mathrm{C}$ for $15 \mathrm{sec}$ and $60^{\circ} \mathrm{C}$ for $1 \mathrm{~min}$. Data were analyzed according to the manufacturer's guidelines and were obtained as Ct values (the cycle number at which logarithmic PCR plots cross a calculated threshold line) and used to determine $\mathrm{dCt}$ values $(\mathrm{dCt}=\mathrm{Ct}$ of the target gene minus $\mathrm{Ct}$ of the internal reference, 18S).

Sequences of oligonucleotide primers and probes for $11 \beta$-HSD 1 and H6PDH were as follows; 11 1 -HSD1: forward 5'-AGGAAAGCTCATGGGAGGACTAG-3', reverse 5'-ATGGTGAATATCATCATGAAAAAGA TTC-3', and probe 5'-CATGCTCATTCTCAACGAC ATCACCAACA-3'. H6PDH: forward 5'-AGAACT CGGGACGTTTTTCAA-3', reverse 5'-GGGCCACA GCCTGCTT-3', and probe 5'-TAAGTAATGGT CGACGCGGTACATCTCGTCG-3'.

\section{Western blot analysis}

Twenty micrograms of protein from cell lysates (siRNA experiments) was analysed by SDS-PAGE using $12 \cdot 5 \%$ gels on a Bio-Rad Mini-Protean II apparatus (Bio-Rad, Richmond, CA, USA). Ten micrograms of human liver homogenate, produced as previously reported (Ricketts et al. 1998), was loaded as a control. Western blotting was performed as reported previously (Ricketts et al. 1998). Membranes were incubated with validated polyclonal antibody to human 11/-HSD1 (The Binding Site, Birmingham, UK) at a dilution of 1:1000 for $16 \mathrm{~h}$ at $4{ }^{\circ} \mathrm{C}$. Following $3 \times 10 \mathrm{~min}$ washes in PBS-containing $0 \cdot 1 \%$ Tween 20, membranes were incubated with secondary antibody (goat anti-sheep IgG peroxidase conjugate; The Binding Site, Birmingham, UK) at a dilution of 1:75 000 for $1.5 \mathrm{~h}$ at room temperature. Bound peroxidase-conjugated $\mathrm{Ig}$ was visualized using ECL detection kit (Amersham Pharmacia Biotech, Buckinghamshire, UK) by exposing membranes to X-ray film (Kodak).

\section{1ß-hydroxysteroid dehydrogenase assay}

Assays of $11 \beta$-HSD1 activity were performed by incubating intact cells with $1 \mathrm{ml}$ of serum-free culture media with $100 \mathrm{nM}$ cortisone (oxo-reductase) or cortisol (dehydrogenase) and tritiated tracer for 3-16 h, or (for transfected CHO cells) with $25 \mathrm{nM}$ corticosterone or 11-dehydrocorticosterone for $42 \mathrm{~h}$. After incubation, media was transferred to a glass tube and steroids were extracted with $5 \mathrm{ml}$ of dichloromethane. Next the aqueous phase was removed and dichloromethane phase concentrated to $100 \mathrm{ul}$ which was then spotted on a TLC silica plate. Steroids were separated by thin layer chromatography using a mobile phase of ethanol and chloroform (8:92) and quantitated using a Bioscan 2000 image analyzer (Lablogic, Sheffield, UK) or a phosphorimager (Fuji FLA-2000, Raytek Scientific Ltd, Sheffield, UK). Protein levels were assayed using a 96-well plate assay kit (Bio-Rad Laboratories Inc., Hercules, CA, USA). All experiments were carried out in triplicate.

\section{Data analysis}

Values are given as means \pm S.E. of $(n)$ separate experiments. Statistical analysis of comparisons among groups was undertaken using the one-way analysis of variance (for normal distribution) or Mann-Whitney rank sum test (for non-normal distribution). Nonparametric Spearman correlation has been used to analyze preadipocyte data. $P$ values of less than $0 \cdot 05$ were accepted as statistically significant.

\section{Results}

\section{Overexpression of H6PDH, G6PD and 11ß-HSD in $\mathrm{CHO}$ cells}

In transfected cell lines, $11 \beta$-HSD1 is predominantly an oxo-reductase (Low et al. 1994). The important exception to this is CHO cells, in which transiently transfected $11 \beta$-HSD 1 encodes both oxo-reductase and dehydrogenase activities at approximately equal levels (Agarwal et al. 1989). Co-transfection of CHO cells with an expression plasmid encoding H6PDH together with an 11 -HSD1 plasmid increased oxo-reductase activity compared with controls transfected with $11 \beta$-HSD1 plasmid and empty pcDNA3.1 vector; $68 \cdot 7 \pm 3 \cdot 0$ vs $42 \cdot 4 \pm 2 \cdot 4 \%$ respectively, $P<0 \cdot 05$ (Fig. 1 A). Simultaneously, dehydrogenase activity was virtually eliminated; $4 \cdot 0 \pm 0 \cdot 7 \quad$ vs $27 \cdot 2 \pm 1 \cdot 9 \%$ in controls, 

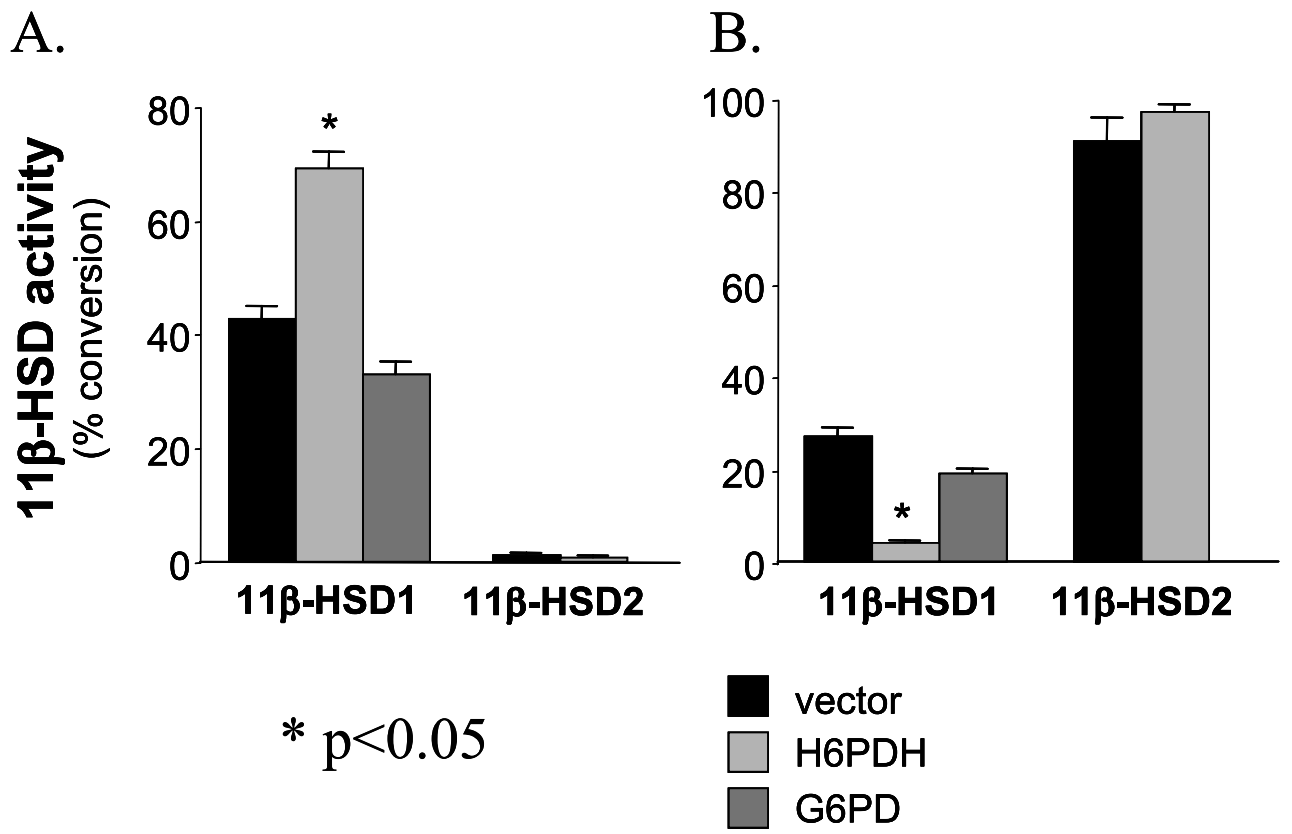

Figure 1 Oxo-reductase $(A)$ and dehydrogenase $(B)$ activity of two isozymes of $11 \beta-H S D$. CHO cells were co-transfected with $11 \beta-\mathrm{HSD} 1$ or $11 \beta-\mathrm{HSD} 2$ and $\mathrm{H} 6 \mathrm{PDH}$ or G6PD. * $P<0.05$.

$P<0 \cdot 05$ (Fig. 1B). In contrast, H6PDH had no effect on reaction direction of $11 \beta$-HSD2; $0.8 \pm 0.3 \%$ vs $1 \cdot 2 \pm 0 \cdot 5 \%$ in controls (oxo-reductase) and $97 \cdot 5 \pm 1 \cdot 6 \%$ vs $91 \cdot 0 \pm 5 \cdot 2 \%$ in controls (dehydrogenase) (Figs 1A and B). Furthermore co-transfection of $\mathrm{CHO}$ cells with an expression plasmid encoding the cytosolic enzyme G6PD failed to produce any differences in oxo-reductase $(32 \cdot 7 \pm 2 \cdot 4 \%$ vs controls $42 \cdot 4 \pm 2 \cdot 4 \%)$ or dehydrogenase $(19 \cdot 0 \pm 1 \cdot 2 \%$ vs controls $27 \cdot 2 \pm 1 \cdot 9 \%)$ activities (Figs 1A and $\mathrm{B})$.

\section{Suppression of 11ß-HSD1 and H6PDH in HEK 293T1 cells by siRNA}

Introduction of either $11 \beta$-HSD1 or H6PDH siRNA in HEK 293T1 cells caused a significant decrease in the target mRNA levels compared with cells transfected with a control/scrambled siRNA (Silencer Negative Control $\# 1)$; $11 \beta$-HSD 1 mRNA fold change: $0 \cdot 48 \pm 0 \cdot 07, n=6$, $P<0 \cdot 01$, H6PDH mRNA fold change: $0 \cdot 46 \pm 0 \cdot 12$, $n=6, \quad P<0 \cdot 01$, (Fig. 2A). Furthermore, 11 $\beta$-HSD 1 protein levels were significantly decreased in cells transfected with $11 \beta$-HSD 1 siRNA compared with cells transfected with H6PDH siRNA or a scrambled siRNA control (Fig. 2B). Both 11 $\beta$-HSD1 dehydrogenase and oxo-reductase activities were similarly decreased in intact cells from 11ß-HSD1 siRNA-transfected cells compared with scrambled siRNAs: dehydrogenase; $0.64 \pm 0 \cdot 11, \quad n=6, \quad P<0 \cdot 001, \quad$ and oxo-reductase; $0 \cdot 85 \pm 0 \cdot 14, n=6, P<0 \cdot 05$ (Fig. 2C).
In contrast, transfection with $\mathrm{H} 6 \mathrm{PDH}$ siRNA had no effect on 11ß-HSD1 protein levels (Fig. 2B), but did cause a significant decrease in oxo-reductase activity in intact cells compared with cells transfected with scrambled siRNA; fold change $0.81 \pm 0.13, n=6$, $P<0 \cdot 05$, (Fig. 2C). Of note, $11 \beta$-HSD1 dehydrogenase activity was concomitantly increased by transfection with H6PDH siRNA, fold change $1 \cdot 11 \pm 0 \cdot 09, n=6, P<0 \cdot 05$ (Fig. 2C).

\section{Correlation between 11ß-HSD1 activity and H6PDH expression in human omental preadipocytes}

To investigate whether H6PDH similarly regulates $11 \beta$-HSD 1 reaction direction in intact primary cultures endogenously expressing 11ß-HSD1, oxo-reductase activity and H6PDH mRNA levels were assayed in human omental preadipocytes. Significant oxoreductase activity was seen in all cultured preadipocyte preparations.

A significant $(P<0.05)$ negative correlation between $\mathrm{dCt}$ for H6PDH [Median 11.04; 10.64 (25\%), 11.6 $(75 \%) \quad \mathrm{C}]$ and $11 \beta$-HSD1 oxo-reductase activity [Median 37.0; 21.02 (25\%), 59.60 (75\%) CI] in omental human preadipocytes was observed. This illustrates a positive correlation between $\mathrm{H} 6 \mathrm{PDH}$ mRNA and $11 \beta$-HDS1 oxo-reductase activity. To present the positive directionality of the correlation, H6PDH mRNA levels have been expressed as - $\mathrm{dCt}$, and its relation with $11 \beta$-HSD1 oxo-reductase has been shown 


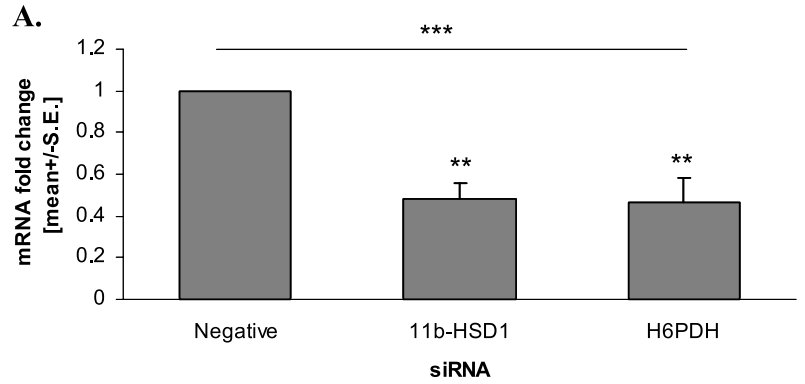

$* * * p<0.001$ (One Way ANOVA)

** $p<0.01$

B.

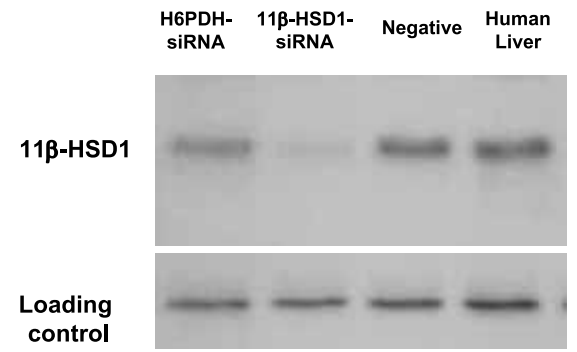

C.

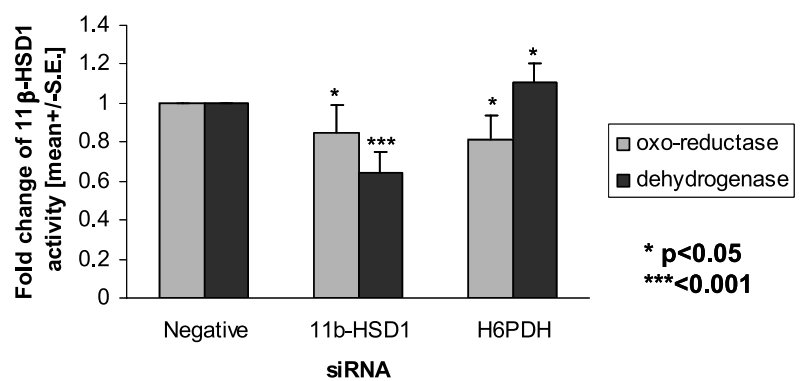

Figure 2 Suppression of 11ß-HSD1 and H6PDH in HEK 293T1 cells by siRNA. (A) HEK 293 T1 were transfected with $11 \beta$-HSD1, H6PDH or scrambled-siRNAs (Negative) for $48 \mathrm{~h}$. Compared to scrambled siRNA control, mRNA levels for $11 \beta$-HSD1 and H6PDH were suppressed in cells transfected with the respective siRNAs. (B) Immunoblot showing suppression of $11 \beta$-HSD1 protein levels by $11 \beta$-HSD1-siRNA but not by H6PDH-siRNA or scrambled-siRNAs (Negative); human liver was used as positive control. (C) Resulting $11 \beta-H S D 1$ oxo-reductase and dehydrogenase activities were both reduced by $11 \beta$-HSD1-siRNA whereas oxo-reductase activity was decreased and dehydrogenase activity simultaneously increased upon transfection with H6PDH-siRNA. ${ }^{* \star} P<0.01 ;{ }^{\star \star \star} P<0.001$ (one-way ANOVA).

in Fig. 3A. The change in $11 \beta$-HSD1 oxo-reductase levels occurred despite no significant difference in $11 \beta$-HSD 1 mRNA levels (dCt: $12 \cdot 34 \pm 0 \cdot 25$, mean \pm s.E.).

As previously reported in a larger cohort (Tomlinson et al. 2002), we observed a significant $(P<0 \cdot 05)$ inverse correlation between BMI [Median 29.3; $26 \cdot 2$ (25\%),
$33 \cdot 1(75 \%) \mathrm{CI}$ and $11 \beta$-HSD 1 oxo-reductase activity [Median 37.0; 21.02 (25\%), 59.60 (75\%) CI] in cultured preadipocytes (Fig. 3B), but importantly no correlation between BMI and $11 \beta$-HSDl mRNA levels $(P=0 \cdot 18)$ (data not shown).

Moreover, H6PDH mRNA levels inversely correlated with BMI as reflected by a positive correlation $(P=0.012)$ between dCt for H6PDH expression [Median $11 \cdot 04 ; 10.64(25 \%), 11 \cdot 6(75 \%) \mathrm{CI}$ ] and BMI [Median $29 \cdot 3 ; 26 \cdot 2$ (25\%), 33.1 (75\%) CI. Again, H6PDH mRNA levels have been expressed as - dCt and the correlation between $-\mathrm{dCt}$ and $\mathrm{BMI}$ has been shown in Fig. 3C.

Across adipocyte differentiation, 11ß-HSD1 oxoreductase activity increased $(11 \cdot 8 \pm 3 \cdot 6$ vs $66 \cdot 1 \pm$ $21.9 \mathrm{pmol} / \mathrm{mg} / \mathrm{h}$, day $1 \mathrm{vs}$ day $14, P<0.05)$ whilst dehydrogenase activity decreased $(104 \cdot 0 \pm 25 \cdot 1$ vs $17 \cdot 3 \pm 5 \cdot 0 \mathrm{pmol} / \mathrm{mg} / \mathrm{h}$, day 1 vs day $14, P<0 \cdot 01$ ), (Fig. 4A). Concomitantly, H6PDH mRNA levels increased $5 \cdot 3$-fold as measured by quantitative real-time PGR (dCt $13.5 \pm 0.7$ vs $11.5 \pm 0.5$, day 1 vs day $14, P<0.05$ ) (Fig. $4 \mathrm{~B})$. There was no significant difference in $11 \beta$-HSD 1 mRNA expression during omental preadipocytes differentiation (Fig. 4B).

\section{Discussion}

The oxo-reductase activity of $11 \beta$-HSD 1 has emerged as an important mechanism by which glucocorticoid concentrations can be regulated in a tissue-specific fashion. By generating cortisol in hepatocytes (Jamieson et al. 1995, Ricketts et al. 1998), adipocytes (Bujalska et al. 1997b), osteoblasts (Bland et al. 1999, Cooper et al. 2000) and ocular tissues (Rauz et al. 2001), this enzyme may be involved in the pathogenesis of obesity, metabolic syndrome/diabetes mellitus, glucocorticoid-induced osteoporosis and glaucoma. In liver for example, $11 \beta$-HSD 1-mediated oxo-reductase activity stimulates hepatic gluconeogenesis in fasted mice (Kotelevtsev et al. 1997). Mice lacking 11ß-HSD1 resist hyperglycemia upon stress or feeding (Kotelevtsev et al. 1997). Conversely, transgenic over-expression of $11 \beta$-HSD1 in liver leads to insulin resistance and hypertension, but without obesity (Paterson et al. 2004). The role of $11 \beta$-HSD 1 in the regulation of adipose tissue mass is an area of much scientific interest and speculation. The profound effects of cortisol upon adipose tissue biology are exemplified in patients with Cushing's syndrome who develop marked and reversible central obesity (Rebuffe-Scrive et al. 1988). We have demonstrated enhanced $11 \beta$-HSD1 expression in omental compared with subcutaneous depots, and have suggested that central obesity might arise from the autocrine generation of cortisol within omental adipose tissue - 'Cushing's disease of the omentum' through the expression of 


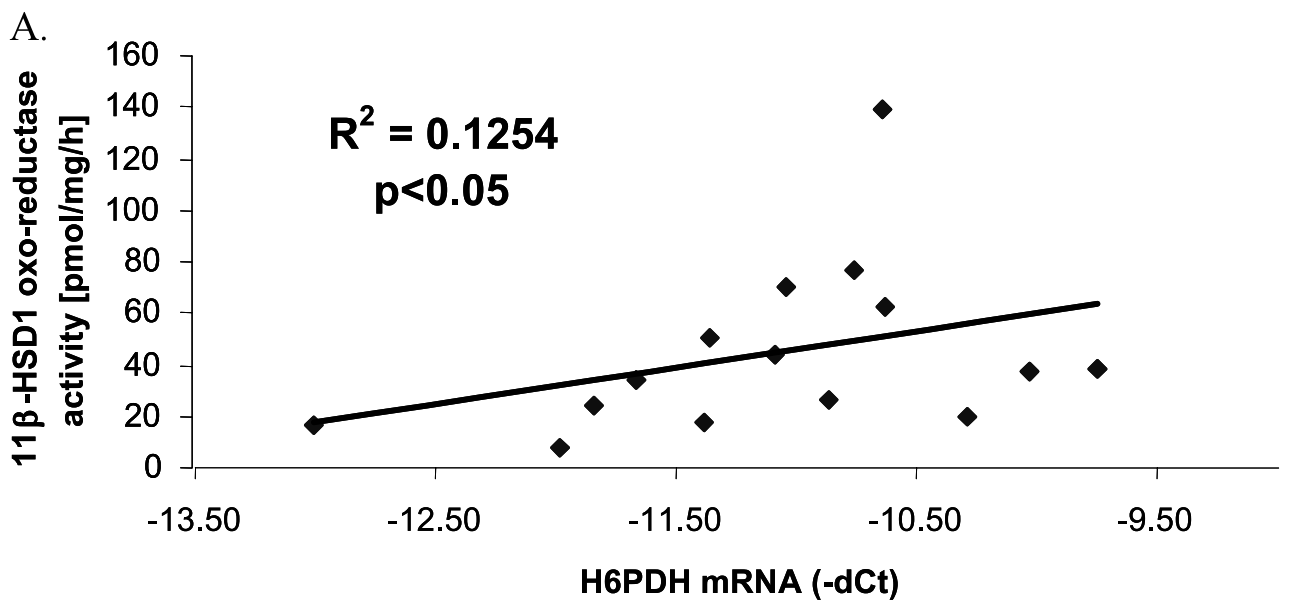

B.

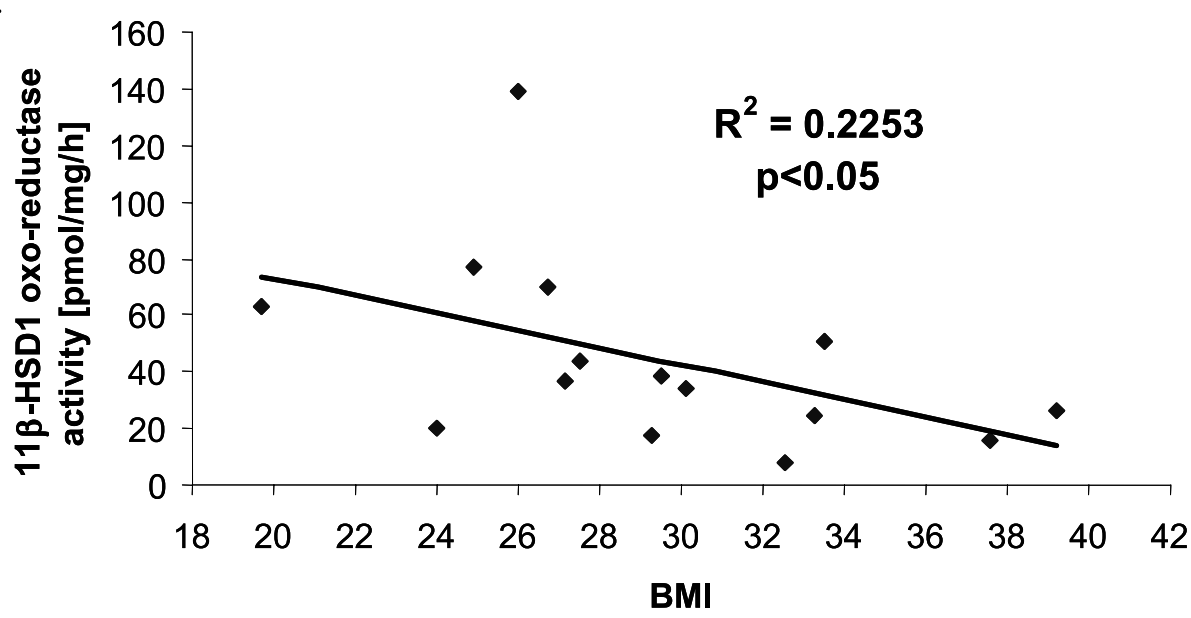

C.

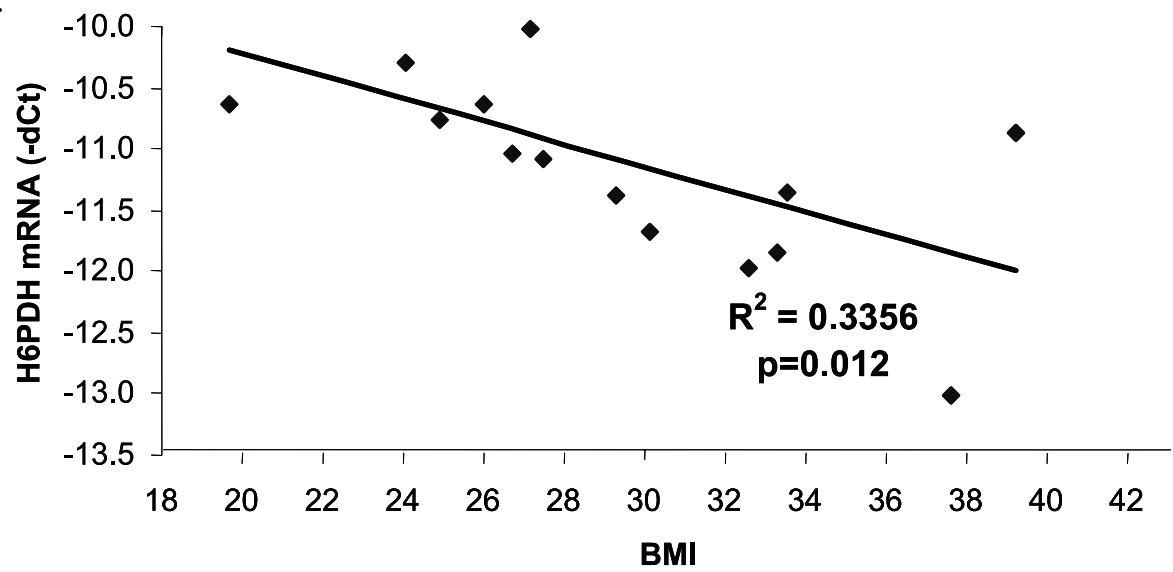

Figure 3 (A) Significant positive correlation between H6PDH mRNA levels and 11 $\beta$-HSD1 oxo-reductase activity in human omental preadipocytes. (B) $11 \beta-H S D 1$ oxo-reductase activity in omental preadipocytes in relation to BMI from 15 female patients, showing a significant negative association. (C) H6PDH mRNA expression versus BMI from 15 female patients, showing a significant negative correlation. 


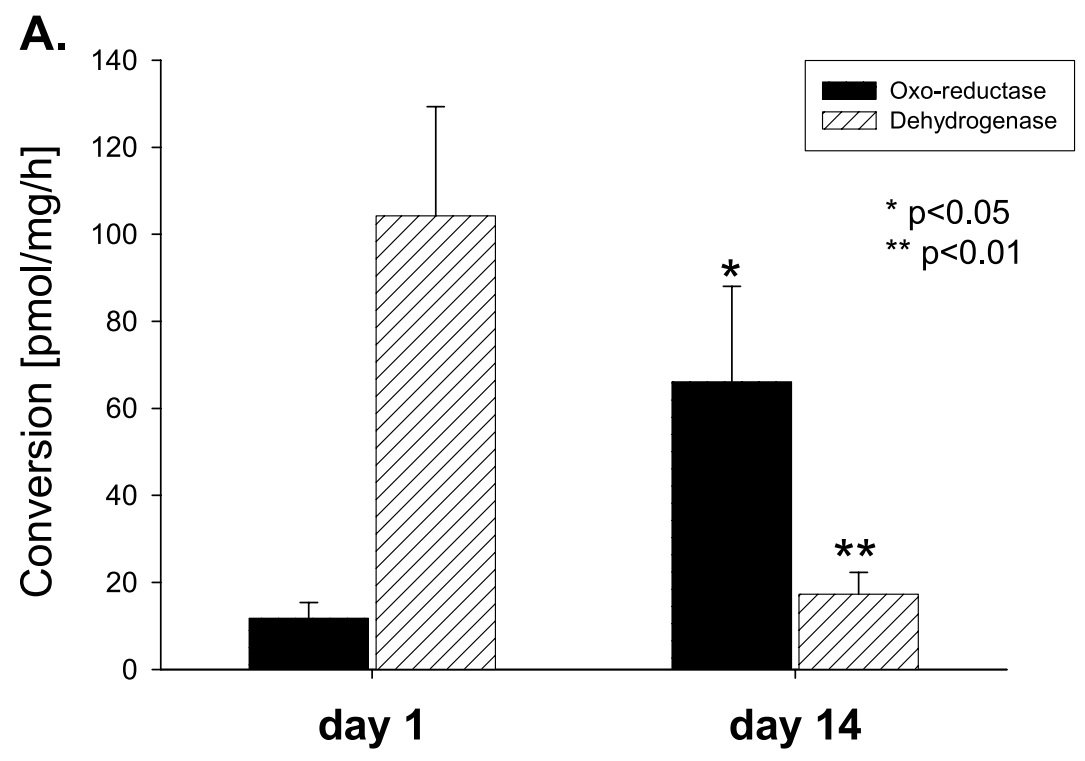

B.

\begin{tabular}{|l|c|c|c|}
\hline mRNA expression & Day 1 & Day 14 & P value \\
\hline H6PDH fold change & 1 & 5.3 & \\
\hline H6PDH dCt & 13.5 & 11.5 & $\mathrm{P}<0.05$ \\
\hline H6PDH se & 0.7 & 0.5 & \\
\hline $11 \beta-H S D 1 \mathrm{dCt}$ & 12.1 & 12.6 & $\mathrm{P}=0.3$ \\
\hline $11 \beta-H S D 1$ se & 0.4 & 0.3 & \\
\hline
\end{tabular}

Figure 4 (A) Change from 11ß-HSD1 dehydrogenase activity to oxo-reductase in human omental preadipocytes differentiated for 14 days, $n=12$. (B) Increase in H6PDH mRNA expression (but not in 11 $\beta$-HSD1) concomitant with an increase in oxo-reductase activity in differentiated preadipocyte cultures, $n=12$. ${ }^{\star} P<0.05$; ${ }^{\star *} P<0.01$

11ß-HSD 1 (Bujalska et al. 1997b). However, subsequent studies have shown, if anything, a $10-20 \%$ global reduction in 11 $\beta$-HSD1 expression in obese subjects, although expression within adipose tissue in obesity is still debated (Stewart et al. 1999, Tomlinson et al. 2002). Nevertheless, recent animal data have highlighted the beneficial effects of administration of selective $11 \beta$ HSD 1 inhibitors upon insulin sensitivity and body weight (Alberts et al. 2003). The effects of $11 \beta$-HSD 1 upon adipose tissue biology depend upon site of expression and enzyme directionality. Cortisol inhibits proliferation of preadipocytes yet stimulates differentiation to adipocytes (Tomlinson et al. 2002). Immediately following isolation of preadipocytes, dehydrogenase activity predominates (Bujalska et al. 2002) which would enhance proliferation. However, once established in cell culture, activity is predominantly oxo-reductase (Bujalska et al. 1997b) and serves to promote adipogen- esis (Bujalska et al. 1999). This is most elegantly demonstrated in transgenic mice over-expressing $11 \beta$ HSD1 under the adipocyte specific aP2 promoter who develop central obesity as a consequence of increased adipocyte size (Masuzaki et al. 2001). Determining the factors regulating directionality of $11 \beta$-HSD 1 activity in human adipose tissue is therefore of crucial importance.

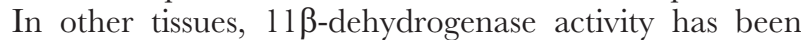
reported in intact cell preparations with the direction of $11 \beta$-HSD 1 catalysis appearing to vary according to physiological or developmental status of a particular cell type. In Leydig and neuronal cells, as well as in human bone, both $11 \beta$-dehydrogenase and oxo-reductase activities have been observed (Ge et al. 1997, Leckie et al. 1998, Jellinck et al. 1999, Cooper et al. 2000). Only oxo-reductase activity has been detected in kidney cells of monkey origin (Cos-7) transiently transfected with rat $11 \beta$-HSD 1 cDNA (Low et al. 1994). However, in most 
cell models, stably transfected with human $11 \beta$-HSD1 cDNA into HEK 293 cells (Bujalska et al. 1997a) or transiently transfected with rat $11 \beta-\mathrm{HSD} 1$ into $\mathrm{CHO}$ cells (Agarwal et al. 1989), both oxo-reductase and dehydrogenase activity are reported. These studies have used different cell models and cDNA/expression constructs that might explain data inconsistency. Yet in every case where oxo-reductase activity is identified, it is reduced or lost when cells are disrupted or the enzyme purified (Monder \& Lakshmi 1989, Monder et al. 1991). This striking change in directionality between intact cells and homogenates is apparently a consequence of the specific intracellular localization of $11 \beta$-HSD1 within the lumen of the ER (Ozols 1995), where H6PDH generates the reduced co-substrate, NADPH (Ozols 1993). Although NADPH generation within the ER lumen is potentially of critical importance to cellular function, at present there is little known about the cellular localization of the catalytic domains of other ER reductases, with the exception of $11 \beta-\mathrm{HSD} 1$. H6PDH is present at high levels within tissues known to express $11 \beta$-HSD1 (Beutler \& Morrison 1967), and blocking the transport of glucose-6-phosphate into isolated rat liver

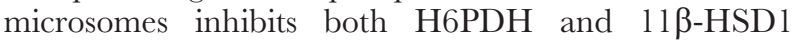
activities (Gerin \& Van Schaftingen 2002, Banhegyi et al. 2004). These findings complement the observation that patients with CRD have functional mutations in $H 6 P D$ in association with intronic mutations in $H S D 11 B 1$ that attenuate 11 $\beta$-HSD1 expression (Draper et al. 2003).

Here we show unequivocally that $\mathrm{H} 6 \mathrm{PDH}$ is able to regulate $11 \beta$-HSD 1 enzyme direction. Co-expression of $11 \beta$-HSD1 with $\mathrm{H} 6 \mathrm{PDH}$ in $\mathrm{CHO}$ cells increased oxo-reductase activity whilst reducing dehydrogenase activity. A parallel study (Atanasov et al. 2004) also showed a 6-fold increase in oxo-reductase with simultaneous 6-fold decrease in dehydrogenase in transiently transfected HEK 293 cells with $11 \beta$-HSD1 and $\mathrm{H} 6 \mathrm{PDH}$, confirming our earlier concept of a close inter-relationship between these two enzymes within the ER. In this study, we have further shown the specificity of $11 \beta$-HSD1 for H6PDH, since co-transfection with a cytosolic NADPH-provider, G6PD, failed to modulate $11 \beta$-HSD 1 reaction direction. In contrast, the overwhelmingly oxidative reaction direction of $11 \beta$-HSD2 was unaffected by co-transfection with $\mathrm{H} 6 \mathrm{PDH}$, as predicted given that the active site of this enzyme faces toward the cytosol (Naray-Fejes-Toth \& Fejes-Toth 1996). This finding is indicative of a pool of co-factors localized within the ER lumen, separated from the cytosolic compartment.

Additionally, we have further endorsed these findings through siRNA 'knock-down' experiments in HEK $293 \mathrm{~T} 1$ cells, where a $50 \%$ reduction in $11 \beta$-HSD 1 or H6PDH mRNA expression was achieved. Reduction in 11ß-HSD1 mRNA altered dehydrogenase and oxo-reductase activities to a similar degree, with the concurrent decrease in $11 \beta$-HSD1 protein expression. Silencing of $\mathrm{H} 6 \mathrm{PDH}$, however, preferably reduced oxo-reductase activity whilst increasing dehydrogenase activity.

Here, we have shown an increase in oxo-reductase $11 \beta$-HSD 1 activity and H6PDH expression in differentiating human omental preadipocytes. In a parallel study, using the 3T3-Ll mouse cell line, a modest increase in H6PDH mRNA levels has been shown to occur across adipogenesis, associated with a highly significant increase in $11 \beta$-HSDl oxo-reductase activity (Atanasov et al. 2004). However, in this cell system, levels of $11 \beta$-HSD1 mRNA also increased more than 100-fold across adipogenesis. This alone could have accounted for the observed significant increase in $11 \beta$-HSD 1 oxo-reductase activity which is not the case in our human cell model where the increase in $11 \beta$-HSD 1 oxo-reductase occurred despite unchanged levels of $11 \beta$-HSD 1 expression.

In addition, in this study, we demonstrate that expression H6PDH mRNA levels decreased with increasing BMI, perhaps explaining the observed decrease in 11 -HSDl oxo-reductase activity in omental preadipocytes in obese patients (Tomlinson et al. 2002). Our earlier studies have shown that glucocorticoids inhibit preadipocyte proliferation (Tomlinson et al. 2002); thus the impaired oxo-reductase activity may increase the number of proliferating preadipocytes in visceral depots. Because $11 \beta$-HSD 1 mRNA levels in human omental adipose tissue are poorly correlated with BMI (Tomlinson et al. 2002), we hypothesize that the 'set-point' of $11 \beta$-HSD1 reaction direction may be contributing more to the pathogenesis of central obesity than its absolute expression levels. On this note, it is interesting to speculate that earlier studies that inferred increased oxo-reductase activity in obese subjects, based upon an increase in measured dehydrogenase activity, might not represent the in vivo situation as this reflects the amount of enzyme present but not its directionality (Rask et al. 2001, Wake et al. 2003). To summarize, in this study we now demonstrate a direct relationship between $11 \beta$-HSD1 oxo-reductase activity and H6PDH expression in human omental preadipocytes and cell line models.

In terms of human disease, the targeted inhibition of $11 \beta$-HSD 1 as a therapeutic strategy in patients with the metabolic syndrome is an exciting advance (Alberts et al. 2002, Andrews et al. 2003, Sandeep et al. 2004, Rauz et al. 2003). In turn, the identification of H6PDH as a determinant of oxo-reductase activity in adipose tissue raises the possibility that $\mathrm{H} 6 \mathrm{PDH}$ itself could be a promising therapeutic target in treating central obesity. Indeed it is tempting to speculate that some of the 'selective 11ß-HSD1' inhibitors obtained through cellbased high throughput screening assays, might actually be inhibitors of H6PDH rather than $11 \beta$-HSD1. 


\section{Acknowledgements}

We thank surgeons from the Birmingham Women's Hospital for assistance in adipose tissue collection and Val Lyons, David Bennett, Ricardo de Sousa Peixoto, Jonathan Seckl and Martin Hewison for help, advice and discussions. We are grateful to Dr Phil J Mason (Imperial College London, UK) for providing us with H6PDH and G6PD cDNA/plasmids.

This work was funded by an MRC co-operative core grant and by the Wellcome Program Fund (WT065998/Z/01Z). P White is supported by the Audry Newman Rapoport Distinguished Chair in Pediatric Endocrinology. The authors declare that there is no conflict of interest that would prejudice the impartiality of this scientific work.

\section{References}

Agarwal AK, Monder C, Eckstein B \& White PC 1989 Cloning and expression of rat cDNA encoding corticosteroid 11 beta-dehydrogenase. Fournal of Biological Chemistry 264 18939-18943.

Agarwal AK, Tusie-Luna MT, Monder C \& White PC 1990 Expression of $11 \beta$-hydroxysteroid dehydrogenase using recombinant vaccinia virus. Molecular Endocrinology 4 1827-1832.

Alberts P, Engblom L, Edling N, Forsgren M, Klingstrom G, Larsson C, Ronquist-Nii Y, Ohman B \& Abrahmsen L 2002 Selective inhibition of 11 beta-hydroxysteroid dehydrogenase type 1 decreases blood glucose concentrations in hyperglycaemic mice. Diabetologia 45 1528-1532.

Alberts P, Nilsson C, Selen G, Engblom LO, Edling NH, Norling S, Klingstrom G, Larsson C, Forsgren M, Ashkzari M et al. 2003 Selective inhibition of 11 beta-hydroxysteroid dehydrogenase type 1 improves hepatic insulin sensitivity in hyperglycemic mice strains. Endocrinology 144 4755-4762.

Andrews RC, Rooyackers O \& Walker BR 2003 Effects of the 11 beta-hydroxysteroid dehydrogenase inhibitor carbenoxolone on insulin sensitivity in men with type 2 diabetes. Fournal of Clinical Endocrinology and Metabolism 88 285-291.

Atanasov AG, Nashev LG, Schweizer RA, Frick C \& Odermatt A 2004 Hexose-6-phosphate dehydrogenase determines the reaction direction of 11 beta-hydroxysteroid dehydrogenase type 1 as an oxoreductase. FEBS Letters 571 129-133.

Banhegyi G, Benedetti A, Fulceri R \& Senesi S 2004 Cooperativity between 11 bbeta -hydroxysteroid dehydrogenase type 1 and hexose-6-phosphate dehydrogenase in the lumen of the endoplasmic reticulum. Fournal of Biological Chemistry $\mathbf{2 5}$ 27017-27021.

Beutler E \& Morrison M 1967 Localization and characteristics of hexose 6-phosphate dehydrogenase (glucose dehydrogenase). Journal of Biological Chemistry 242 5289-5293.

Biason-Lauber A, Suter SL, Shackleton CH \& Zachmann M 2000 Apparent cortisone reductase deficiency: a rare cause of hyperandrogenemia and hypercortisolism. Hormone Research $\mathbf{5 3}$ 260-266.

Bland R, Worker CA, Noble BS, Eyre LJ, Bujalska IJ, Sheppard MC, Stewart PM \& Hewison M 1999 Characterization of 11 beta-hydroxysteroid dehydrogenase activity and corticosteroid receptor expression in human osteosarcoma cell lines. Fournal of Endocrinology $161455-464$.

Brown RW, Chapman KE, Kotelevtsev Y, Yau JL, Lindsay RS, Brett L, Leckie C, Murad P, Lyons V, Mullins JJ et al. 1996
Cloning and production of antisera to human placental 11 beta-hydroxysteroid dehydrogenase type 2. Biochemical fournal $\mathbf{3 1 3}$ $1007-1017$

Bublitz C \& Steavenson S 1988 The pentose phosphate pathway in the endoplasmic reticulum. Fournal of Biological Chemistry $\mathbf{2 6 3}$ 12849-12853.

Bujalska I, Shimojo M, Howie A \& Stewart PM 1997a Human 11 beta-hydroxysteroid dehydrogenase: studies on the stably transfected isoforms and localization of the type 2 isozyme within renal tissue. Steroids 62 77-82.

Bujalska IJ, Kumar S \& Stewart PM $1997 b$ Does central obesity reflect 'Cushing's disease of the omentum'? Lancet 349 1210-1213.

Bujalska IJ, Kumar S, Hewison M \& Stewart PM 1999 Differentiation of adipose stromal cells: the roles of glucocorticoids and 11 beta-hydroxysteroid dehydrogenase. Endocrinology 140 3188-3196.

Bujalska IJ, Walker EA, Hewison M \& Stewart PM 2002 A switch in dehydrogenase to reductase activity of 11 beta-hydroxysteroid dehydrogenase type 1 upon differentiation of human omental adipose stromal cells. Fournal of Clinical Endocrinology and Metabolism 87 1205-1210.

Cooper MS, Walker EA, Bland R, Fraser WD, Hewison M \& Stewart PM 2000 Expression and functional consequences of 11 beta-hydroxysteroid dehydrogenase activity in human bone. Bone 27 375-381.

Draper N, Walker EA, Bujalska IJ, Tomlinson JW, Chalder SM, Arlt W, Lavery GG, Bedendo O, Ray DW, Laing I et al. 2003 Mutations in the genes encoding 11 beta-hydroxysteroid dehydrogenase type 1 and hexose-6-phosphate dehydrogenase interact to cause cortisone reductase deficiency. Nature Genetics 34 434-439.

Ge RS, Gao HB, Nacharaju VL, Gunsalus GL \& Hardy MP 1997 Identification of a kinetically distinct activity of 11 beta-hydroxysteroid dehydrogenase in rat Leydig cells. Endocrinology 138 2435-2442.

Gerin I \& Van Schaftingen E 2002 Evidence for glucose-6-phosphate transport in rat liver microsomes. FEBS Letters 517 257-260.

Hauner H, Schmid P \& Pfeiffer EF 1987 Glucocorticoids and insulin promote the differentiation of human adipocyte precursor cells into fat cells. Fournal of Clinical Endocrinology and Metabolism 64 832-835.

Jamieson PM, Chapman KE, Edwards CR \& Seckl JR 199511 beta-hydroxysteroid dehydrogenase is an exclusive 11 betareductase in primary cultures of rat hepatocytes: effect of physicochemical and hormonal manipulations. Endocrinology 136 $4754-4761$.

Jamieson A, Wallace AM, Andrew R, Nunez BS, Walker BR, Fraser R, White PC \& Connell JM 1999 Apparent cortisone reductase deficiency: a functional defect in 11 beta- hydroxysteroid dehydrogenase type 1. Fournal of Clinical Endocrinology and Metabolism $843570-3574$.

Jamieson PM, Walker BR, Chapman KE, Andrew R, Rossiter S \& Seckl JR 200011 beta-hydroxysteroid dehydrogenase type 1 is a predominant 11 beta-reductase in the intact perfused rat liver. Fournal of Endocrinology 165 685-692.

Jellinck PH, Pavlides C, Sakai RR \& McEwen BS 199911 beta-hydroxysteroid dehydrogenase functions reversibly as an oxidoreductase in the rat hippocampus in vivo. Fournal of Steroid Biochemistry and Molecular Biology 71 139-144.

Jones CG, Hothi SK \& Titheradge MA 1993 Effect of dexamethasone on gluconeogenesis, pyruvate kinase, pyruvate carboxylase and pyruvate dehydrogenase flux in isolated hepatocytes. Biochemical fournal 289 821-828.

Kimura K, Endou H, Sudo J \& Sakai F 1979 Glucose dehydrogenase (hexose 6-phosphate dehydrogenase) and the microsomal electron transport system. Evidence supporting their possible functional relationship. Fournal of Biochemistry 85 319-326. 
Kotelevtsev Y, Holmes MC, Burchell A, Houston PM, Schmoll D, Jamieson P, Best R, Brown R, Edwards CR, Seckl JR et al.1997 11 beta-hydroxysteroid dehydrogenase type 1 knockout mice show attenuated glucocorticoid-inducible responses and resist hyperglycemia on obesity or stress. PNAS 94 14924-14929.

Laing I, Adams JE, Wood PJ, Taylor NF \& Ray DW 2002 Cortisone Reductase deficiency (11 $\beta$-hydroxysteroid dehydrogenase type 1) presenting with features of late onset congenital adrenal hyperplasia. Endocrine Abstracts 3 P264.

Lakshmi V \& Monder C 1988 Purification and characterization of the corticosteroid $11 \beta$ - dehydrogenase component of the rat liver $11 \beta$-hydroxysteroid dehydrogenase complex. Endocrinology 123 2390-2398.

Leckie CM, Welberg LA \& Seckl JR 199811 beta-hydroxysteroid dehydrogenase is a predominant reductase in intact rat Leydig cells. Fournal of Endocrinology 159 233-238.

Livingstone DE \& Walker BR 2003 Is 11 beta-hydroxysteroid dehydrogenase type 1 a therapeutic target? Effects of carbenoxolone in lean and obese Zucker rats. Fournal of Pharmacology and Experimental Therapeutics 305 167-172.

Low SC, Chapman KE, Edwards CRW \& Seckl JR 1994 Liver-type 11-beta-hydroxysteroid dehydrogenase cdna encodes reductase but not dehydrogenase-activity in intact mammalian cos-7 cells. Fournal of Molecular Endocrinology 13 167-174.

Mason PJ, Stevens D, Diez A, Knight SW, Scopes DA \& Vulliamy TJ 1999 Human hexose-6-phosphate dehydrogenase (glucose 1-dehydrogenase) encoded at 1p36: coding sequence and expression. Blood Cells, Molecules and Diseases 25 30-37.

Masuzaki H, Paterson J, Shinyama H, Morton NM, Mullins JJ, Seckl JR \& Flier JS 2001 A transgenic model of visceral obesity and the metabolic syndrome. Science 294 2166-2170.

Monder C \& Lakshmi V 1989 Evidence for kinetically distinct forms of corticosteroid $11 \beta$-dehydrogenase in rat liver microsomes. Journal of Steroid Biochemistry 32 77-83.

Monder C, Lakshmi V \& Miroff Y 1991 Kinetic studies on rat liver 11 beta-hydroxysteroid dehydrogenase. Biochimica and Biophysica Acta 1115 23-29.

Naray-Fejes-Toth A \& Fejes-Toth G 1996 Subcellular localization of the type 211 beta-hydroxysteroid dehydrogenase. A green fluorescent protein study. Fournal of Biological Chemistry 271 15436-15442.

Nikkila H, Tannin GM, New MI, Taylor NF, Kalaitzoglou G, Monder C \& White PC 1993 Defects in the HSD1l gene encoding 11 beta-hydroxysteroid dehydrogenase are not found in patients with apparent mineralocorticoid excess or 11-oxoreductase deficiency. Fournal of Clinical Endocrinology and Metabolism 77 687-691.

Odermatt A, Arnold P, Stauffer A, Frey BM \& Frey FJ 1999 The $\mathrm{N}$-terminal anchor sequences of 11 beta-hydroxysteroid dehydrogenases determine their orientation in the endoplasmic reticulum membrane. Fournal of Biological Chemistry $\mathbf{2 7 4}$ 28762-28770

Ozols J 1993 Isolation and the complete amino acid sequence of lumenal endoplasmic reticulum glucose-6-phosphate dehydrogenase. PNAS 90 5302-5306.

Ozols J 1995 Lumenal orientation and post-translational modifications of the liver microsomal 11 beta-hydroxysteroid dehydrogenase. Fournal of Biological Chemistry 270 2305-2312.

Paterson JM, Morton NM, Fievet G, Kenyon CJ, Holmes MC, Staels B, Seckl JR \& Mullins JJ 2004 Metabolic syndrome without obesity: Hepatic overexpression of 11 beta-hydroxysteroid dehydrogenase type 1 in transgenic mice. PNAS 101 7088-7093.

Persico MG, Viglietto G, Martini G, Toniolo D, Paonessa G, Moscatelli C, Dono R, Vulliamy T, Luzzatto L \& D’Urso M 1986 Isolation of human glucose-6-phosphate dehydrogenase
(G6PD) cDNA clones: primary structure of the protein and unusual 5' non-coding region. Nucleic Acids Research 14 2511-2522.

Rask E, Olsson T, Soderberg S, Andrew R, Livingstone DE, Johnson O \& Walker BR 2001 Tissue-specific dysregulation of cortisol metabolism in human obesity. Fournal of Clinical Endocrinology and Metabolism 86 1418-1421.

Rauz S, Cheung CM, Wood PJ, Coca-Prados M, Walker EA, Murray PI \& Stewart PM 2003 Inhibition of 11

beta-hydroxysteroid dehydrogenase type 1 lowers intraocular pressure in patients with ocular hypertension. Quarterly foumal of Medicine 96 481-490.

Rauz S, Walker EA, Shackleton CH, Hewison M, Murray PI \& Stewart PM 2001 Expression and putative role of 11 beta-hydroxysteroid dehydrogenase isozymes within the human eye. Investigative Ophthalmology and Visual Science 42 2037-2042.

Rebuffe-Scrive M, Krotkiewski M, Elfverson J \& Bjorntorp P 1988 Muscle and adipose tissue morphology and metabolism in Cushing's syndrome. Fournal of Clinical Endocrinology and Metabolism $671122-1128$.

Ricketts ML, Verhaeg J, Bujalska I, Howie AJ, Rainey WE \& Stewart PM 1998 Immunochistological Localization of Type 1 $11 \beta$-Hydroxysteroid Dehydrogenase in Human Tissues. Fournal of Clinical Endocrinology and Metabolism 83 1325-1335.

Sandeep TC, Yau JL, MacLullich AM, Noble J, Deary IJ, Walker BR \& Seckl JR 200411 Beta-hydroxysteroid dehydrogenase inhibition improves cognitive function in healthy elderly men and type 2 diabetics. PNAS $1016734-6739$.

Stegeman JJ \& Klotz AV 1979 A possible role for microsomal hexose-6-phosphate dehydrogenase in microsomal electron transport and mixed-function oxygenase activity. Biochemical and Biophysical Research Communications 87 410-415.

Stewart PM, Boulton A, Kumar S, Clark PM \& Shackleton CH 1999 Cortisol metabolism in human obesity: impaired cortisone-cortisol conversion in subjects with central adiposity. Fournal of Clinical Endocrinology and Metabolism 84 1022-1027.

Tomlinson JW, Sinha B, Bujalska I, Hewison M \& Stewart PM 2002 Expression of 11 beta-hydroxysteroid dehydrogenase type 1 in adipose tissue is not increased in human obesity. Fournal of Clinical Endocrinology and Metabolism 87 5630-5635.

Voice MW, Seckl JR, Edwards CR \& Chapman KE 1996 $11 \beta$-Hydroxysteroid dehydrogenase type 1 expression in 2S FAZA hepatoma cells is hormonally regulated: a model system for the study of hepatic glucocorticoid metabolism. Biochemistry $\mathbf{3 1 7}$ 621-625.

Wake DJ, Rask E, Livingstone DE, Soderberg S, Olsson T \& Walker BR 2003 Local and systemic impact of transcriptional up-regulation of 11 beta-hydroxysteroid dehydrogenase type 1 in adipose tissue in human obesity. Fournal of Clinical Endocrinology and Metabolism 88 3983-3988.

Walker EA, Clark AM, Hewison M, Ride JP \& Stewart PM 2001 Functional expression, characterization, and purification of the catalytic domain of human 11-beta -hydroxysteroid dehydrogenase type 1. Fournal of Biological Chemistry 276 21343-21350.

Williams LJ, Lyons V, MacLeod I, Rajan V, Darlington GJ, Poli V, Seckl JR \& Chapman KE 2000 C/EBP regulates hepatic transcription of 11 beta -hydroxysteroid dehydrogenase type 1. A novel mechanism for cross-talk between the G/EBP and glucocorticoid signaling pathways. Fournal of Biological Chemistry 275 30232-30239.

Received 18 January 2005 Accepted 27 January 2005 